\title{
A Comparative Study on IgG-ELISA, IgM-IFT and Kato-Katz Methods for Epidemiological Purposes in a Low Endemic Area for Schistosomiasis
}

\author{
Rita Maria da Silva*/+, Herminia Y Kanamura**, Eide D Camargo*, \\ Silvia G Chiodelli*, Paulo M Nakamura*, Cybele Gargioni*, \\ Sylvia AG Vellosa*, José LF Antunes***
}

\author{
*Instituto Adolfo Lutz, Secretaria da Saúde, Av. Dr. Arnaldo 351, $8^{\circ}$ andar, 01246-902 São Paulo, SP, Brasil \\ **Faculdade de Ciências Farmacêuticas, Universidade de São Paulo, SP, Brasil ***Faculdade de Odontologia, \\ Universidade de São Paulo, SP, Brasil
}

The high sensitivity and the possibility of automation of the enzyme-linked-immunosorbent-assay (ELISA) has indicated this technique as one of the most useful serological test for epidemiological studies. In the present study, an ELISA for detection of IgG antibodies against adult worm antigens (IgG-ELISA) was investigated for epidemiological purposes, in a rural area of the municipality of Itariri (São Paulo, Brazil). Blood on filter paper (1,180 samples) from about 650 schoolchildren were submitted to ELISA and the data compared to the results of the parasitological method of Kato-Katz and also to the IgM-IFT (immunofluorescence test for IgM antibodies to gut associated antigens). The prevalence rates respectively of $8.5 \%, 43.0 \%$, and $56.2 \%$ by the Kato-Katz, IgG-ELISA, and IgM-IFT methods suggest the poor sensitivity of the parasitological method for detection of Schistosoma mansoni eggs in individuals with low worm burden, situation commonly observed in low endemic areas. These results can partially explain the poor degree of agreement between the IgG-ELISA and the Kato-Katz, as suggested by the Kappa index of 0.170. Otherwise, the Kappa index of 0.675 showed substantial agreement between the two serological tests. Some discrepancy of results between the two serological techniques must be better investigated.

Key words: Schistosoma mansoni - ELISA - low endemic area - seroepidemiology

In areas where schistosomiasis is endemic, the diagnosis of the infection is commonly based only on parasitological methods. However, even after repeated stool examinations, those methods frequently fail to detect low-intensity Schistosoma mansoni infections (Barreto et al. 1990, De Vlas et al. 1992, Engels et al. 1996). In the State of São Paulo, Brazil, some areas are of low endemicity for schistosomiasis, and the majority of the individuals have low worm burden. Investigations in these areas have demonstrated that the prevalence rates obtained by serological tests were always higher than the ones obtained by parasitological methods. In such situation, the serological methods can stand for an important tool to estimate prevalence rates closer to the real situation (Kawazoe et al. 1981, Hoshino-Shimizu et al. 1986, Dias et al. 1992a, b).

\footnotetext{
This work was partially supported by Fapesp. ${ }^{+}$Corresponding author. Fax: +55-11-853.3505. E-mail: ritamara@usp.br Received 4 May 1998 Accepted 31 August 1998
}

The immunofluorescence test for the detection of IgM antibodies against $S$. mansoni gut associated polysaccharide antigens (IgM-IFT) have demonstrated to be an important tool in field studies (Kanamura et al. 1998a, b). The IgM-IFT showed high degree of sensitivity for diagnosis of both, acute and chronic schistosomiasis, and also good specificity (Silva et al. 1992), but it is not a practical technique to work with a large number of samples. The subjectivity of the interpretation and the time spent at the microscopy of fluorescence represent some limitations of the IFT that make difficult its automation.

The enzyme-linked immunosorbent assay (ELISA) has been elected as one of the most useful serological test for epidemiological studies, because of its high sensitivity for the diagnosis of schistosomiasis, depending on the S. mansoni antigen used in the test and the possibility of automation.

In the present study we evaluated the diagnostic potential of an ELISA for the detection of $\operatorname{IgG}$ antibodies against total worm antigen (IgGELISA), for seroepidemiological purposes, in one 
of the regions of São Paulo with low transmission of $S$. mansoni.

\section{MATERIALS AND METHODS}

Studied area and population - The study was carried out in a rural area of the municipality of Itariri, in the Vale do Rio Ribeira de Iguape. From 1991 to 1993, a group of about 650 children from four schools was followed up by parasitological (Kato-Katz) and serological (IgM-IFT) diagnostic methods. In five surveys, carried out one for each semester, about 3,000 blood samples were collected on filter paper and stored at $-20^{\circ} \mathrm{C}$. From this total, about $30 \%$, were used in this study. By the simple randomized sampling method, from the 1 st to 5 th survey respectively 242, 223, 242, 234 and 239 blood samples were selected. So, a total of 1,180 blood samples were evaluated in the present study. They were submitted simultaneously to IgGELISA and IgM-IFT. The serological data were compared each other and in relation to the parasitological Kato-Katz method.

Blood samples - Blood samples obtained from finger pricks were collected on Whatman $3 \mathrm{MM}^{\mathrm{O}}$ filter paper. The filter papers were dried at room temperature, stored in a plastic bag, and kept at $20^{\circ} \mathrm{C}$. The dried blood spot discs were cut from the Whatman filter paper using a punch 8 - $\mathrm{mm}$ in diameter. The paper disc were eluted in $120 \mu \mathrm{l}$ of $0.01 \mathrm{M}, \mathrm{pH}$ 7.2, phosphate buffer solution (PBS), incubating overnight at $4^{\circ} \mathrm{C}$. The serum dilution after elution and removal of the paper disc was estimated to be 1:16 (Ferreira et al. 1982) and used for the IgM-IFT. For the IgG-ELISA, from the initial 1:16, a dilution of 1:128 was prepared in PBS containing $0.05 \%$ Tween 20 , and $2 \%$ skim milk.

IgG-ELISA - The enzyme-linked immunosorbent assay was carried out for detection of $\operatorname{IgG}$ antibodies to total worm soluble antigen, as described by Valli et al. (1997). The ELISA polystyrene plates were coated with $50 \mu$ of the worm antigen $(10 \mathrm{mg} / \mathrm{ml})$, diluted in a carbonate buffer solution, pH 9.6. The cut-off value was established based on the mean optical density of negative control sera plus two standard deviations.

IgM-IFT - The immunofluorescence test for detection of $\operatorname{IgM}$ antibodies against gut-associated adult $S$. mansoni antigens was performed as described by Silva et al. (1992).

Parasitological diagnosis - From each schoolchild, in each survey, only one fecal sample was examined by the Kato-Katz method (Katz et al. 1972). S. mansoni egg counts were expressed in eggs per gram (epg), using the average of egg counts obtained from three slides for each sample.

Data analysis - The analysis of the sensitivity and specificity indices and the determination of
Kappa indices to compare the performance of the diagnostic methods were done using the statistical package of EPIINFO (Dean et al. 1994).

\section{RESULTS}

The schistosomiasis prevalence rates, in each survey, obtained by the serological IgG-ELISA and IgM-IFT methods were significantly higher than those obtained by the parasitological Kato-Katz method. The percentages of positivity obtained by the IgG-ELISA were significantly lower than those obtained by the IgM-IFT, except for the 2nd survey (Table). In the comparative study between the IgG-ELISA and IgM-IFT results, the Kappa values of $0.675,0.667,0.655,0.617$, and 0.711 were obtained respectively for the 1st to 5th surveys. They indicated, according to Fleiss (1985), substantial agreement between the two serological tests.

The comparative analysis between the results of the IgM-IFT obtained in the present study, after different periods of storage at $-20^{\circ} \mathrm{C}$, and those previously obtained, soon after blood collection, showed a high degree of agreement. The Kappa indices of $0.933,0.833,0.826,0.721$, and 0.908 were determined respectively for the 1 st to 5 th surveys.

A very poor agreement was observed when the results of IgG-ELISA were compared to Kato-Katz, with Kappa indices of 0.170, 0.081, 0.226, 0.104, and 0.247 , respectively for the 1 st to 5 th surveys.

\section{DISCUSSION}

The schistosomiasis vigilance and control programs in São Paulo have routinely applied as diagnostic method only the stool examination. But it is known that the commonly used Kato-Katz technique can give underestimate prevalence indices when applied in low endemic areas (De Vlas \& Gryseels 1992). In some areas of low S. mansoni transmission, like the ones in São Paulo or in Venezuela, the egg excretion of the majority of the infected individuals used to be below 100 epg of feces. In such areas, the success of control strategies might be limited by the low diagnostic efficiency of the traditionally applied Kato-Katz stool examination (Noya et al. 1992, Dias et al. 1992a,b).

In the present study, the performance of an IgGELISA with $S$. mansoni worm antigen for detection of IgG antibodies (Valli et al. 1997) was evaluated for epidemiological purposes in a low endemic area. The results of IgG-ELISA were analyzed in comparison to the results of IgM-IFT and the parasitological stool examination. One stool specimen from each individual was collected, and for each fecal sample three slides were prepared and examined by the Kato-Katz method. Only the cases with 


\section{TABLE}

Percentages of positivity obtained by the serological IgG-ELISA and IgM-IFT methods, and by the parasitological Kato-Katz method, in five surveys, carried out on a selected group of schoolchildren in the municipality of Itariri, São Paulo

\begin{tabular}{|c|c|c|c|c|c|c|}
\hline \multirow{3}{*}{ Survey } & \multirow{3}{*}{ Period } & \multicolumn{3}{|c|}{ Serological methods } & \multirow{2}{*}{\multicolumn{2}{|c|}{$\begin{array}{c}\text { Parasitological method } \\
\text { Kato-Katz }\end{array}$}} \\
\hline & & \multirow[t]{2}{*}{$\mathrm{N}_{1}$} & \multicolumn{2}{|c|}{$\%$ Positivity $\quad(\% \mathrm{P})$} & & \\
\hline & & & ELISA-IgG & RIF-IgM & $\mathrm{N}_{2}$ & $\% \mathrm{P}$ \\
\hline $1 \mathrm{st}$ & 1st sem / 91 & 242 & $\begin{array}{c}43.0^{a} \\
(36.7-49.5)^{\tilde{a}}\end{array}$ & $\begin{array}{c}56.2^{a} \\
(49.7-62.5)\end{array}$ & 199 & $\begin{array}{c}8.5 \\
(5.2-13.5)\end{array}$ \\
\hline 2 nd & 2nd sem / 91 & 223 & $\begin{array}{c}60.5^{d} \\
(53.7-66.9)\end{array}$ & $\begin{array}{c}63.7^{d} \\
(56.9-69.9)\end{array}$ & 170 & $\begin{array}{c}8.2 \\
(4.7-13.7)\end{array}$ \\
\hline $3 r d$ & 1st sem / 92 & 242 & $\begin{array}{c}44.6^{c} \\
(38.2-51.1)\end{array}$ & $\begin{array}{c}52.9^{c} \\
(46.4-59.3)\end{array}$ & 194 & $\begin{array}{c}11.8 \\
(7.8-17.4)\end{array}$ \\
\hline 4th & 2nd sem / 92 & 234 & $\begin{array}{c}56.0^{b} \\
(49.3-62.4)\end{array}$ & $\begin{array}{c}66.7^{b} \\
(60.2-72.6)\end{array}$ & 194 & $\begin{array}{c}6.2 \\
(3.4-10.8)\end{array}$ \\
\hline 5 th & 1st sem / 93 & 239 & $\begin{array}{c}62.7^{c} \\
(56.2-68.8)\end{array}$ & $\begin{array}{c}69.9^{c} \\
(63.6-75.5)\end{array}$ & 196 & $\begin{array}{c}17.8 \\
(12.9-24.1)\end{array}$ \\
\hline
\end{tabular}

ã $(95 \%$ confidence interval); $a$ : $\mathrm{p}<0,01 ; b: \mathrm{p}<0,05 ; c: \mathrm{p}<0,1 ; d: \mathrm{p}>0,40 ; \mathrm{N} 1$ : number of blood samples submitted to the serological tests; N2: number of fecal samples submitted to the Kato-Katz technique.

S. mansoni eggs in the fecal examination were submmited to oxamniquine treatment.

The prevalence rates obtained by IgG-ELISA and IgM-IFT were significantly higher than those obtained by the parasitological Kato-Katz method, confirming the lack of sensitivity of the latter in low endemic areas (Table). Some authors have shown that underestimate prevalence rates were obtained when only one fecal sample from each individual is examined in epidemiological studies of low endemic areas (De Vlas \& Gryseels 1992, Engels et al. 1996). The egg counts in the parasitologically positive fecal samples from the individuals selected for this study varied from 8 to 1,792 epg, with geometric means of 45.0, 45.5, 36.2, 41.5 and $38.0 \mathrm{epg}$, respectively for the 1st to 5th surveys. Such low egg counts, indicating small number of parasites in the infected population, and the use of only one fecal sample from each individual are certainly the responsable for the reduced parasitological prevalence rates, when compared to the serological data.

The percentages of positivity were significantly higher for IgM-IFT than for IgG-ELISA, except for the 2nd survey (Table). When the results of the two serological tests were compared each other, a not acceptable agreement was detected, as can be indicated by the analysis of the Kappa indices, varying from 0.616 to 0.711 . The discordant results were more frequently observed in the positive IgM-IFT and negative IgG-ELISA cases.

When the IgM-IFT results obtained in the two different phases were compared, a good level of agreement was in general detected, with Kappa indices from 0.826 to 0.933 . These results indicate the good stability of the IgM antibodies on filter paper when kept at $-20^{\circ} \mathrm{C}$ and the suitability of the storage method for field studies. In the fourth survey a relatively low Kappa indices of 0.721 was detected. In this survey, some problem related to the interpretation of the fluorescence intensity pattern was detected.

The ELISA, as applied in this study, showed to be less sensitive than IgM-IFT, probably because of the quality of the total crude worm antigen used for the detection of IgG antibodies. In spite of its limitation, because of the possibility of automation, being more adequate for working with large amount of samples, it can be a useful tool for field studies, to classify different areas according to the level of $S$. mansoni transmission.

\section{AKNOWLEDGEMENTS}

To Ana Lúcia dos Santos Aranda and Ivete Aparecida Rodrigues de Lima Calixto for technical assistance.

\section{REFERENCES}

Barreto ML, Smith DH, Sleigh AC 1990. Implications of faecal egg count variation when using the KatoKatz method to assess Schistosoma mansoni infections. Trans $R$ Soc Trop Med Hyg 84: 554-555.

Dean AG, Dean JÁ, Coulombier D, Brendel KA, Smith DC, Burton AH, Dicker RC, Sullivan KM, Fargan RF, Arner TG 1994. Epi Info, version 6: a word processing database, and statistics program for epi- 
demiology on microcomputer. Center of Disease Control and Prevention, Atlanta, Georgia, U.S.A.

De Vlas SJ, Gryseels B 1992. Underestimation of Schistosoma mansoni prevalences. Parasitol Today 8: 274-277.

De Vlas SJ, van Oortmarssen GJ, Gryseels B 1992. Validation of a model for variations in Schistosoma mansoni egg counts. Trans $R$ Soc Trop Med Hyg 86: 645.

Dias LCS, Kanamura HY, Hoshino-shimizu S, Glasser CM, Carvalho JF, Silva LC 1992a. Field trials for immunodiagnosis with reference to Schistosoma mansoni, p. 39-47. In NR Bergquist Immunodiagnostic Approches in Schistosomiasis. John Wiley \& Sons, Chichester.

Dias LCS, Marçal-Jr O, Glasser CM, Kanamura HY, Hotta LC 1992b. Control of schistosomiasis mansoni in a low transmission area. Mem Inst Osvaldo Cruz 87 (Suppl. IV): 233-239.

Engels D, Sinzinkayo E, Gryseels B 1996. Day-to-day egg count fluctuation in Schistosoma mansoni and its operational implications. Am J Trop Med Hyg 54: 319-324.

Ferreira CS, Carvalho ME 1982. Padronização de uso de papel-filtro como suporte de material para reações sorológicas. Rev Bras Malariol 34: 82-86.

Fleiss AR 1985. Clinical epidemiology, p. 185-186. In The Architecture of Clinical Research, W.B. Saunders Co., Philadelphia.

Hoshino-Shimizu S, Camargo MC, Kawada HYK, Silva LC, Dias LCS 1986. Aspectos sorológicos e soroepidemiológico da esquistossomose mansônica. Anais Acad Mineira Med 14 (Supl.): 67-89.

Kanamura HY, Dias LCS, Glasser CM, Patucci RMJ,
Vellosa SAG, Antunes JLF 1998a. A comparative study on specific antibodies (IgM and IgA) and parasitological findings for epidemiological purposes in an endemic area of low transmission of $S$. mansoni. Rev Inst Med Trop S Paulo 40: 45-90.

Kanamura HY, Dias LCS, Glasser CM, Silva RM, Patucci RMJ, Chiodelli SG, Addis D 1998b. Detection of IgM antibodies to Schistosoma mansoni gutassociated antigens for the study of the dynamics of schistosomiasis transmission in a low endemic area. Rev Inst Med Trop S Paulo (in press).

Kawazoe U, Hoshino-Shimizu S, Correa NS, Silva LC, Pinto ACM, Camargo ME 1981. An immunoepidemiological study of schistosomiasis mansoni in Paraiba's Valley, São Paulo, Brazil. Rev Inst Med Trop S Paulo 23: 36-40.

Katz N, Chaves A, Pellegrino J 1972. A simple device for quantitative stool thick-smear technique in schistosomiasis mansoni. Rev Inst Med Trop S Paulo 14: 397-400.

Noya BA, Noya O, Balzan C, Cesari IM 1992. New approaches for the control and erradication of schistosomiasis in Venezuela. Mem Inst Osvaldo Cruz 87 (Suppl. IV): 227-231.

Silva RM, Silva MIPG, Vellosa SAG, Kanamura HY 1992. Pesquisa de anticorpos IgM contra tubo digestivo do verme para o diagnóstico da esquistossomose mansônica. Rev Bras Pa Clin 28: 39-42.

Valli LCP, Kanamura HY, Silva RM, Silva MIPG, Vellosa SAG, Garcia ET 1997. Efficacy of an enzime-linked immunosorbent assay in the diagnosis of and serologic distinction between acute and chronic Schistosoma mansoni infection. Amer J Trop Med Hyg 57: 358-362. 